\title{
Our Second Son is Number One: Numbers in Recent Japanese Given Names
}

\section{Nasz Drugi Syn jest Numerem Jeden: Liczby we Współczesnych Imionach Japońskich}

\author{
Ivona Barešová \\ PALACKY UNIVERSITY \\ KŘİŽKOVSKÉHO 14, OLOMOUC 771 80, CZECH REPUBLIC \\ ivona.baresova@upol.cz
}

\begin{abstract}
Japanese given names reflect through their kanji selection particular perceived or anticipated aspects concerning their bearers, providing an insight into the changing values of Japanese society. In the past, numbers were used in names mainly to refer to the order of birth, the time of birth, or, in the case of large numbers, to express a wish for longevity. Within the larger historical context, this paper focuses on the use of kanji representing numbers in the names of children born in the last ten years (2008-2017), exploring the recent reasons for their choice and what values and priorities of recent Japanese parents they reflect.
\end{abstract}

\begin{abstract}
Abstrakt
Japońskie imiona rodowe zawierają $\mathrm{w}$ sobie określone znaki kanji, którym przypisane są określone cechy, pożądane dla ich właściciela Stanowi to obraz zmian w wartościach wyznawanych przez współczesne społeczeństwo japońskie. Dawniej liczby wykorzystywano $\mathrm{w}$ imionach jedynie $\mathrm{w}$ celu wskazania kolejności w rodzinie, czasu przyjścia na świat lub wyrażenia życzenia długowieczności w przypadkach liczb o dużej wartości. Artykuł ten skupia się na zastosowaniu kanji oddających liczby w imionach dzieci urodzonych w ciągu ostatnich 10 lat (2008-2017) poddając analizie współczesne kryteria ich doboru a także wartości i priorytety wyznawane przez rodziców małych Japończyków.
\end{abstract}




\section{Introduction}

Contemporary name selection is driven by the parental desire to create a name that will reflect the individual qualities and uniqueness of their child, while having an appealing sound and pleasant overall image, and also fulfilling the myriad other criteria as prescribed by the influential Tamahiyo and other numerous name-giving publications and websites (e.g., Kobayashi 2009, Nakaya 2012, Barešová 2016). Although Japanese names can be written in kanji, kana, or some combination of the two, the overwhelming majority of contemporary names, both male and female, are written in kanji, which, being mostly morphographic, make it possible for the name givers to complement the chosen phonological form with a graphic form that would convey their desired meanings, evoke various images, and call forth various associations. The current selection of kanji used in given names, many of which relate to the natural world (Honda 2005, Makino 2012, Barešová 2016), is very wide, ${ }^{1}$ as parents increasingly choose less frequent kanji in their search for an original name to fit the desired personality and future life of their child.

Kanji representing numbers (漢数字 kansūji ${ }^{2}$ in Japanese) were traditionally more often used in given names, but, despite the greatly expanded choice of kanji used in names today, some of them, namely ('one') and 千 ('thousand'), are still among the most popular kanji in male and female names, respectively. This paper explores the current use of kanji representing numbers in names, compares this to the past, and examines how they fit the various demands of current parents and what values and aspirations for the newborn they reflect. 3

Of the existing kanji representing numbers, 4 the following, which have been more commonly used in given names, are dealt with in this paper: ('one'), 二 ('two'), 三 ('three'), 四 ('four'), 五 ('five'), 六 ('six'), 七 ('seven'), 八 ('eight'), 九 ('nine'), 十 ('ten'), 百 ('hundred'), 千 ('thousand') and 万 ('ten thousand'). While all these kanji can be found in given names, they were used in different periods with differing frequency and for various

1 The kanji permitted for use in names are regulated, and it is not possible to register a name written in other than the permitted kanji, of which there are currently almost three thousand. For a detailed account of the individual extensions to the list of kanji that can be used in names see Atsuji (2005).

2 The Hepburn system of romanization, which follows English pronunciation, is used in this paper. Long vowels are transcribed using the macron.

3 The theme of kanji representing numbers within given names is also addressed from the historical development perspective by the same author in the Czech paper Čisla $v$ japonských rodných jménech $v$ minulosti a dnes [Numbers in Japanese Given Names: Past and Present], which was published in Nový Orient 73 (1) in 2018. Conversely, the present paper focuses on the parental motivations for the most recent use of kanji representing numbers within the context of the contemporary name selection process.

4 There are many more kanji representing numbers, including, for example, kanji representing large numbers, such as 億 $(100,000,000)$, or a separate set of the so-called 大字 (daiji, lit. 'big characters') used mainly in legal and financial documents (e.g., 壱 instead of - to prevent undesired modifications, such as changing - to + ). 
reasons. In the past the smaller numbers were most commonly used to express birth order or commemorate the time of birth, whereas the larger numbers were mainly used in female names to symbolize longevity.

\section{Description of the data}

The frequency of these kanji representing numbers in current names, the motivation for their use, and the meanings they are meant to convey were examined based on a corpus of 10,337 Japanese names of children born 2008-2017 (5,020 male and 5,317 female names) collected over the course of several years from the website Bebi karend $\bar{a}$ [Baby Calendar]. ${ }^{5}$ Each of the entries contains the graphic and phonological forms of the name, the year of birth, the gender of the child, and also a short commentary (nazuke episōdo) by the parents explaining the motivation for selecting the particular name, its intended interpretation, the main criteria for their selection, and so forth. Examples of these are used throughout the paper to demonstrate particular points under discussion. Examples of older names and their interpretation come from another corpus, collected through a questionnaire given by the author, resulting in 1,115 names of people born 1880-1999.

The corpus of 10,337 recent names contains 395 examples of the kanji under discussion: 175 in male names and 220 in female names (see the table below). The most frequent of these kanji in the male names is - ('one'), and for girls it is 千 ('thousand'). According to a research conducted by Jugaku (1979: 172), the same was true for the names of children born in the 1960s, when - was even the most frequently used kanji overall for boys. The numbers in the table may seem low, but as was already mentioned above, contemporary names feature a great variety of kanji, and thus the 129 occurrences make - ('one') the eleventh most frequent kanji in the corpus of boy's names. For comparison, it placed tenth in the 2017 Meiji Yasuda Insurance Company ranking of top 25 kanji in male names. 6 千 ('thousand'), with 87 appearances in the corpus, ranks 31st among girl's names. 七 ('seven') and 百 ('hundred') also stand out.

Table 1: Occurrences of kanji representing numbers in the corpus of names bestowed 2008-2017

\begin{tabular}{|c|c|c|}
\hline & Names of boys & Names of girls \\
\hline 二('one') & 129 & 29 \\
\hline 二('two') & 4 & 4 \\
\hline 三 ('three') & 6 & 4 \\
\hline 元('four') & 3 & 1 \\
\hline 五 ('five') & 1 & 1 \\
\hline 六('six') & 1 & 4 \\
\hline
\end{tabular}

5 Available at https://baby-calendar.jp/ (access date: 30 March 2018).

6 Between 2012 and 2017 it ranked between the ninth and fifteenth position. 


\begin{tabular}{|c|c|c|}
\hline 七 ('seven') & 3 & 49 \\
\hline 八 ('eight') & 2 & 4 \\
\hline 九 ('nine') & 0 & 0 \\
\hline 十 ('ten') & 2 & 0 \\
\hline 百 ('hundred') & 2 & 35 \\
\hline 干 ('thousand') & 18 & 87 \\
\hline 万 ('ten & 4 & 2 \\
\hline thousand') & 4 & \\
\hline
\end{tabular}

\section{Number one: from birth order to individuality and uniqueness}

One of the reasons numbers were commonly used in names in the past was to reflect the order of birth, which was actually quite important, because it was the firstborn son who usually inherited the family property and business and became the next head of the hierarchically structured extended family. The expression of birth order was a typical feature for male names.

Such names were of one of the following patterns. The simpliest names resembled mere numbering and were formed by a kanji expressing the order of birth and a typically masculine end kanji 郎 ('son'). Thus the firstborn was 一郎 Ichirō, the second-born 二郎 Jirō ${ }^{7}$, the third-born 三郎 Saburō, followed by 四郎 Shirō, 五郎 Gorō, etc. This pattern could be also combined with another, preceeding kanji, expressing, for example, a particular character trait or aspiration (ex. 1). A similar pattern is the combination of a kanji carrying a particular meaning with an end kanji expressing the order of birth (ex. 2). In two-kanji compounds the kanji expressing birth order was, in addition to 郎, also complemented with some other typically masculine end kanji. In most cases it was only the names of the firstborn, such as 一雄 Kazuo ('one' + 'man'), 一夫 Kazuo ('one' + 'man, husband'), 一行 Kazuyuki ('one' + 'to go, journey'), 一 治 Kazuharu ('one' + 'to cure, heal, rule'), etc., but, for example, in combination with the end kanji 男 ('man'), there were also names such as 五男 Itsuo ('five' + 'man') and 六男 Mutsuo ('six' + 'man') (ex. 3). The frequency and the very possibility of individual combinations always depends also on the resultant agreeableness of the sound.

ex.1) Parents named their son born in 1929 善四郎 Zenshirō ('virtuous, good' + 'four' + 'son'). He was the fourth of six siblings so they put 四 in his name. The last kanji was adopted from his father's name, 松五郎 Matsugorō ('pine' + 'five' + 'son').

ex.2) Parents named their son born in 1944 平一 Heïchi ('peace' + 'one'). The first kanji comes from the name of their family business and was used in the names of all male members of the family. -

7 太郎 Tarō ('strong' + 'son') was also used for the firstborn and 次郎 Jirō ('next' + 'son') for the second-born. 


\section{Ivona Barešová: Our Second Son is Number One: Numbers in Recent Japanese Given Names}

stands for firstborn. Their second son, born in 1948, was named 平 二 Heiji ('peace' + 'two').

ex.3) Parents named their son born in 1936 六男 Mutsuo ('six' + 'man'), simply because he was born as their sixth child.

Names expressing birth order were given also to girls. 8 At the beginning of the twentieth century the majority of female names were still written in the phonographic kana, and thus a particular intended meaning cannot be determined with certainty, but it is likely that a girl named Ichi or Kazu was firstborn, while Mitsu (Mitsue, Mitsuno or Mitsuyo) could have been third-born (although the word mitsu has also other meanings), Mutsu the sixth-born, Shichi the seventh-born, etc. Female names written in kanji usually featured - ('one'): e.g., 一枝 ('one' + 'branch'), 一江 ('one' + 'inlet'), 一栄 ('one' + 'prosper, flourish') and 一恵 ('one' + 'blessing, grace, kindness'), all read Ichie or Kazue.

In the second half of the twentieth century, as a logical consequence of decreasing natality, only the kanji - ('one'), and less frequently 二 ('two') and 三 ('three'), were still commonly used ( - was a popular end kanji in male names) and now, as is apparent from the corpus, it is mostly -. The kanji 二 appears only sporadically; there were only four such male names and four female names in the corpus. In the male names 琥二郎 Kojirō ('amber' + 'two' + 'son'), 誠二郎 Seijirō ('sincerity' + 'two' + 'son'), 優二郎 Yüjirō ('kind, excellent’ + 'two' + 'son') and 裕二朗 Yūjürō ('abundant' + 'two' + 'cheerful') the use of 二郎/二朗 was motivated by the use of 一郎/太郎 or 一朗 in the names of their older brothers. In female names the selection of the kanji 二 was motivated by the need to match the chosen phonological form (e.g., Niko $\rightarrow$ 二胡/二瑚). The kanji 三 was just as rare: it appeared in six male and four female names, and in only some of them was the choice motivated by birth order.

The majority of the male names utilizing the number one are of the pattern ('one' + another kanji), although the $\bigcirc$ - and $\bigcirc$ 一郎/朗 patterns are used as well. The explanations in the corpus make it clear that the motivation to use the number one to simply mark the firstborn son is not as strong anymore, although it is not uncommon and in some families it has been a long tradition (ex. 4).

ex.4) Parents named their son born in 2010 一輝 Kazuteru ('one' + 'to shine, glitter, sparkle'). They used - in his name because it is tradition in their family going back to the Edo period [before 1868] to include this kanji in the name of the oldest son. [...]

8 In addition to numbers, several other words expressing order were also used as female names, such as Hatsu ('first time, beginning'), Tsugi ('next'), Naka ('middle, the midmost'), and Sue ('last'), the last one expressing the parents' hope that the newborn girl would be their last child (or at least their last girl). 
The kanji - is often chosen for its simplicity, by those who want a name that would be traditional (e.g., of the $\bigcirc$ 一郎/朗 pattern), and/or easy to write and read (ex. 5), as opposed to names with unusual, hard-to-guess phonological forms. 9 The kanji is often adopted from the father's or grandfather's name (ex. 5, 6). This traditional practice of sharing a particular kanji or some other feature in the names of family members is still quite popular even today (cf. Barešová 2016: 40-43) and since this kanji was frequently used in male names of previous generations, it keeps reappearing in currently bestowed names as well.

ex.5) Parents named their son born in 2012 一実 Kazumi ('one' + 'crop, harvest, fruit'). They wanted a name that everyone could read and would be easy to write. They adopted - from his grandfather's name, and chose 実 for its autumn image.

ex.6) Parents named their son born in 2008 一清 Isse ('one' + 'clean, clear, pure'). - was adopted from the name of the father's father, and 清 from the maternal grandfather. [...]

A frequently listed reason for choosing - is the parents' desire to reflect the child's unique existence (ex. 7) and express how important and precious the child is for them (ex. 8, 9).

ex.7) Parents named their son born in 2017 一人 Kazuto ('one' + 'person, man') to express that there is no such other child in the world.

ex.8) Parents named their son born in 2013 一喜 Kazuki ('one' + 'joy, to rejoice'). They expressed through the kanji selection that the day their child was born had been the happiest and most emotive day in their lives.

ex.9) Parents named their son born in 2011 一夢 Kazumu ('one' + 'dream') to express that, after the mother's health problems, the birth of their son is a fulfilment of their only dream (唯一の夢).

And, interestingly, while the kanji - is stereotypically used in the names of the firstborn, it also appears in the names of younger siblings. Examples 10 and 11 demonstrate its use in the name of the oldest child and also in the names of the siblings to show that the parents consider all their children equally important. In examples 12 and 13, is used only in the names of the younger sons.

ex.10) Parents named their first son, born in 2009, 一真 Kazuma ('one' + 'upright, honest'), and consequently used - in the name

9 For this phenomenon see Satō 2007. 


\section{Ivona Barešová: Our Second Son is Number One: Numbers in Recent Japanese Given Names}

of their younger son, 一咲 Issa ('one' + 'to bloom'), to express that both sons are equally important to them.

ex.11) Parents named their third son, born in 2010, 一稀 Hazuki ('one' + 'rare'). They used - in the names of all their children to express that they all are number one to them.

ex.12) Parents named their second son born in 2008 一誠 Issei ('one' + 'truth, sincerity'). The firstborn son's name is 勇誠 Yüsei ('courage, bravery' + 'truth, sincerity'). The choice of 誠 is related to the fact that the father is a fan of the Taiga drama TV series Shinsengumi. ${ }^{10}$

ex.13) Parents named their third son, born in 2014, 一瑠 Ichiru ('one' + 'lapis lazuli'). The names of the two older sons are motivated by an image of the parents' favorite Tahiti, and so is this name. It was inspired by an image of the blue sea horizon they watched from their cottage. The horizon is represented by $\rightarrow$, and the blue color of the sea by 瑠.

Another frequent motivation is a wish for the child to become a unique person who will excel at something, and will have a great (meaning the best) life, etc. In other words, the name bearer or something in his life will be 一番 ichiban ('the best', 'number one') (ex. 14, 15).

ex.14) Parents named their son born in 2010 一陽 Kazuhi ('one' + 'sun'). The father wanted - in the name to express his wish for him to grow up to be a man who is the best at everything. 陽, which the mother chose, comes from the father's name.

ex.15) Parents named their son born in 2010 一翔 Kazuto ('one' + 'to soar, fly'), wishing him to become number one at something and lead an active and successful life.

In girl's names - appears in names such as 一夏 Chinatsu ('one' + 'summer'), 一彩 Hïro ('one' + 'color, colorful'), 一歌 Ichika ('one' + 'song'), 一菜 Ichina ('one' + 'rapeseed blossom'), 一葉 Kazuha ('one' + 'leaf'), 一希 Kazuki ('one' + 'hope'), and especially in the recently popular name Ichika, most frequently written as 一花 ('one' + 'flower, blossom') or 一華 ('one' + 'flower, splendid, gorgeous'). As apparent from the explanations, the popularity of the last mentioned name is strongly influenced by the hit song Sekai ni hitotsu dake no hana（世界に一つだけの花; 'A flower unlike any other in the world'). The image of a unique flower, which can be found nowhere else, perfectly resonates with the ideas of contemporary parents about the individuality and uniqueness of their

10 Shinsengumi (新選組, 'New Selected Group') was a special police force organized by the Bakufu during the late Tokugawa shogunate, which had 誠 in its flag. 
desired child. Also in the other names — means 'the only' (オンリー1), 'individual', 'unique', 'the best', and often expresses the happiness brought by the child's birth.

\section{From a thousand years to abundant love}

The fact that 千 ('thousand') is the most frequent numerical kanji in currently bestowed female names is not merely some recent trend. The harsh conditions and high infant mortality still common in the Meiji and Taishō eras brought forth wishes for a long and healthy life, which could be expressed in a name in various ways, for example through the chrysanthemum, plum and evergreen plants, the crane and the tortoise, which are all symbols of longevity, but also through large numbers, especially one thousand, three thousand and ten thousand. These numbers are associated with the aforementioned animals as, according to Japanese folklore, the crane is believed to live for a thousand years and the tortoise for ten thousand.

These and other large numbers typically appeared in female names. In the Meiji period, it is possible to find simple names written in kana, such as ヤソ Yaso ('eighty'), ヒヤク Hyaku ('hundred'), セン/せん Sen ('thousand'), ミチ/みち Michi ('three thousand') ${ }^{11}$, and まん Man ('ten thousand'). One thousand appeared in a number of other popular female names, such as チョ/ちよ/千代 Chiyo ('thousand' + 'generation'), and likewise チョノ/ちよの Chiyono and 千代子 Chiyoko, チハル Chiharu ('thousand' + 'spring'), チトセ/千歳 Chitose ('thousand years') and 千鶴 Chizuru ('thousand' + 'crane') (see Barešová 2017).

The wish for longevity expressed through 千 ('thousand'), and less frequently 三千 ('three' + 'thousand', i.e. 'three thousand') stayed a popular motif in female names in the following periods, in the above mentioned names 千代子 Chiyoko and 千鶴 Chizuru, and also 千鶴子 Chizuko ('thousand' + 'crane' + 'child, girl'), 千枝子 Chieko ('thousand' + 'branch' + 'child, girl'), 千枝美 Chiemi ('thousand' + 'branch' + 'beauty'), 三千子 Michiko ('three' + 'thousand' + 'child, girl'), 三千代 Michiyo ('three' + 'thousand' + 'generation'), etc.

While 三千 was not found in the present corpus, of the kanji signifying large numbers, 百 ('hundred') also appears in currently bestowed girl's names. Its use seems to be motivated similarly as the use of 千 (cf. examples 16 and 17), but each of these two kanji can be assigned to different phonological forms. 千 is chosen by those who want a name starting with /chi/ (calling their daughter Chì-chan), while 百 is preferred by those who like the name to start with /momo/ (calling their daughter Momo-chan) or $/ \mathrm{mo} /$.

11 'Three thousand' 三千 is usually read in Japanese as sanzen, and 'eighty'八十

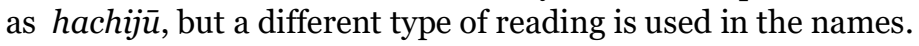




\section{Ivona Barešová: Our Second Son is Number One: Numbers in Recent Japanese Given Names}

ex.16) Parents named their daughter born in 2015 千夏 Chinatsu ('thousand' + 'summer') to stay well and positive for a thousand years.

ex.17) Parents named their daughter born in the summer of 2012 百 夏 Moka ('hundred' + 'summer'). She was born little so they included in the name a wish for her to live a long and healthy life.

As these two examples have just demonstrated, these two kanji are still selected for their associations with longevity. However, more frequently than for the meaning 'forever, for a long time', they are used in the meaning of 'many, a lot' to express various other wishes and aspirations, such as to be loved by many (= a thousand, a hundred) people, to bring others a lot of joy, to be adorable (like lots of flowers), to be very happy, to have many interests, to learn many things, to visit many countries, etc. The following examples, demonstrating such motivation, feature the kanji 千, which appears with greater frequency, but very similarly motivated names featuring 百 can be found as well.

ex.18) Parents named their daughter born in 2011 千愛 Chinari ('thousand' + 'love') [...], wishing her to become a person loved by many people.

ex.19) Parents named their daughter born in 2017 千晴 Chiharu ('thousand' + 'clear, sunny'), wishing her to become a girl who would brighten the hearts of many people.

ex.20) Parents named their daughter born in 2011 千弦 Chizuru ('thousand' + 'bowstring, chord'). [...] They chose 千 for its meaning 'many, a lot', wishing her lots of happiness and fun in her life.

ex.21) Parents named their daughter born in 2017 千咲 Chisaki ('thousand' + 'bloom'). Each of them included one wish in the name. 千 expresses the mother's wish for her to be interested in many things and to challenge many things. 咲 expresses the father's wish for her to have a life full of smile. ${ }^{12}$

A slightly differently motivated name that is worth mentioning here is 千 尋 Chihiro ('thousand' + 'fathom'). This unisex name, which is however more frequently given to girls, has recently gained in popularity especially due to the 2001 animated film Sen to Chihiro no kamikakushi ( 千と千尋の神隠し; Spirited Away), which the present parents enjoyed watching when growing up. The kanji compound means 'great depth' or 'great height', which is in the name associated with greatness of human character, with a person of great depth. The name Chihiro also appears

12 This motivation is not immediately obvious as the meaning 'to smile, laugh' was represented by this kanji in old writing (currently the character 笑 is used instead). 
in various other kanji combinations, such as 千陽 ('thousand' + 'sun'), 千紘 ('thousand' + 'large') or 千裕 ('thousand' + 'abundant, rich').

ex.22) Parents named their daughter born in 2017 千尋 Chihiro ('thousand' + 'fathom'). Their older daughter had 百 ('hundred') in her name so this time they decided for 千. They liked this name for its meaning, wishing their younger daughter to grow up to be a deep-hearted and broad-minded girl.

Just as - is frequently adopted from the name of the boy's grandfather, 千 is relatively frequently adopted from the name of the girl's grandmother. With the meaning 'many, a lot' this kanji can be easily combined with other kanji to create numerous desirable images, which encourages its adoption from generation to generation in either a traditional or modern-looking name.

\section{Lucky seven and commemorating the time of birth}

A typical feature of Japanese name selection is reflecting the time of birth, and numbers are the most straightforward way of achieving this, although today there are more popular means of commemorating the special day. The following examples show names bestowed in the Meiji period reflecting the day and/or the month (ex. 23, 24), and also the year of the era (ex. 25) in which the child was born.

ex.23) Parents named their daughter born on February 3, 1899 二三 Fumi ('two' + 'three'), reflecting the day and month of her birth.

ex.24) Parents named their son born in the Meiji period 十一 Toichi ('ten' + 'one'), reflecting that he was born in November.

ex.25） Parents named their son born in 1903 三十六 Satomu ('three' + 'ten' + 'six'). The graphic form most likely refers to the year of the era, because the year 1903 was the $36^{\text {th }}$ year of the Meiji era.

Names like these three are rare as their graphic form is formed exclusively by kanji representing numbers. It is much more common to find such kanji in combination with other kanji. There was a greater tendency to choose a name reflecting the time of birth if the date had some historical significance, such as the beginning of a new era or some important anniversary. For example, in the first year of the Taishō period (大正, 1912-1926), one of the most popular male names was 正一 Shoichi, ${ }^{13}$ which features the second kanji from the name of the era, and can be interpreted as 'born in the first year of the Taishō period'. In the second year of the era, 正二 Shōji ('born in the second year of the Taishō

13 See the name rankings by Meiji Yasuda Insurance Company. Available at http://www.meijiyasuda.co.jp/profile/etc/ranking/. 


\section{Ivona Barešová: Our Second Son is Number One: Numbers in Recent Japanese Given Names}

period') ranked among the most popular names, and in the third year it was the name 正三 $S h \bar{o} z \bar{o}$ ('born in the third year of the Taishō period'). Naturally, the number in the above mentioned names could also refer to the order of birth as evident, for example, from the fact that the name 正

- Shoichi stayed among the most popular names also in several following years. A similar trend can be observed at the beginning of the Showa period.

The corpus of recent names does not contain many names reflecting the time of birth through numbers. The time of birth is occasionally mentioned with the selection of - (ex. 26). Examples 27-30 feature other numbers, offering various motivation for the selection:

ex.26) Parents named their son 一虎 Itto ('one' + 'tiger'), which reflects his birth in January, in the Year of the Tiger (2010), wishing him to grow up to be a cool, strong boy.

ex.27) Parents named their son born in 2015 三四郎 Sanshirō ('three' + 'four' + 'son'). They had been expecting a girl and so had not thought of a name for a boy. The grandmother suggested giving him a name reflecting his date of birth, March 4 th.

ex.28) Parents named their son born in 2015 彰五 Shōgo ('clear' + 'five'). Originally, they wanted to name him 彰 Akira, but since he was born on May 5th at 5:55 am, they felt it necessary to include number five in his name, as they perceived it as his lucky number.

ex.29) Parents named their daughter born in 2016 輪五 Wago ('ring' + 'five'), because she was born in the year of the Olympic Games in Rio de Janeiro [...].

ex.30) Parents named their daughter born in 2011 八佳 Hachika ('eight' + 'beautiful, excellent'), symbolizing the eight years of marriage after which their long-hoped-for daughter was finally born.

The decreasing use of numbers for this purpose should not, however, lead to the false idea that commemorating the time of birth is likewise falling out of favor. In fact, with the present care to make the name perfect in all respects, many parents make sure to choose a name that well reflects the season, month or even a particular moment of their child's birth. However, rather than using numbers they prefer various plants (especially for girls) and other nature motifs that, in addition to referring to the time of birth, also express various other wishes and aspirations through their symbolism or the images they evoke (Barešová 2015).

The number most often chosen to reflect the time of birth is seven ( $七$ ). It is the second most frequent number in female names, usually chosen for its reading /nana/ or /na/. What makes it a more popular choice is the fact that it is considered a lucky number - ラッキーセブン (rakki sebun, 'lucky seven'), which itself makes it appealing (ex. 31). It also creates interesting images and alludes to various associations. 
For example, in the names 虹七 Niina ('rainbow' + 'seven') and 七彩 Nanase ('seven' + 'color, colorful') it is used for its association with the seven colors of the rainbow, alluding to a person with many talents. The name 七海 Nanami ('seven' + 'sea'), which is by far the most popular name containing $七$, is often meant to refer to the phrase 'Sail the seven seas' (meaning all the seas in the world), creating an idea of a strong, broad-minded and big-hearted personality.

All these various images make the kanji appealing, and even more if the girl's birth is in July and/or the seventh day of a month (ex. 32, 33). Furthemore, on July 7 Tanabata (七夕), the Star Festival, is celebrated in most areas of Japan, which also calls forth various romantic associations and makes it worth commemorating (ex. 34).

ex.31) Parents named their daughter born in 2014 美七 Minana ('beautiful' + 'seven') . The first kanji is adopted from the mother's and grandmother's names. The second kanji - "rakki sebun" was chosen to wish her a lucky and happy life. The number of strokes in the name also brings good luck, so they consider the name perfect in all respects.

ex.32) Parents named their daughter born in 2016 七海 Nanami ('seven' + 'sea'), [...] as she was born in July (七), on Marine (海) Day [a national holiday].

ex.33) Parents named their second daughter 七海 Nanami ('seven’ + 'sea'). [...] She was born with lots of 7s: on July 7, 2017, at 20:07 and had $47.4 \mathrm{~cm}$. Their older daughter had 帆 ('sail') in her name, reflecting the summer season, and so the name 七海, featuring number seven and the sea, seemed just perfect. [...]

ex.34) Parents named their daughter born in 2011 琴七 Kotona ('koto' 14 + 'seven'). They wanted to include the number seven in her name as she was born on the day of Tanabata [...].

\section{Conclusion}

Kanji add meaning to a Japanese name, directly or indirectly expressing aspirations for the individual child, usually within the context of the prevalent cultural values. Some kanji that were frequently used in names in the past have fallen into disuse, while some have appeared in names only recently, but kanji representing numbers can be found in the names of any period. The numerical kanji that are more frequently used, especially - ('one') in male names and 千 ('thousand'), 百 ('hundred') and 七 ('seven') in female names, are those that not only match the chosen phonological form, but also have a good image

14 A traditional Japanese stringed musical instrument. 


\section{Ivona Barešová: Our Second Son is Number One: Numbers in Recent Japanese Given Names}

and the potential to express, in combination with another kanji, aspirations and priorities desired by the current generation of parents.

The decreasing birthrate has narrowed the range of numbers used to reflect birth order in names. Only the number one is still common for this purpose, and even then, expressing birth order is no longer even the main motivation for its choice. Furthermore, the number one now appears in the names of younger siblings as well. Its selection is often motivated by the parents' desire to express the emotional bond to their children, the importance of their birth, their individuality and uniqueness, and the parents' wish for them to grow up to be an exceptional personality.

While the kanji 千 and 百 are still associated with long life, they are combined with a wider range of kanji than before to create various new motifs, such as those of abundant love, joy and beauty, expressing currently desired aspirations for girls.

The last kanji discussed in this paper, 七, is frequently used in female names to commemorate the time of birth. This traditional practice is still popular, in fact, for many current parents it is one of the main selection criteria to choose a name that is "in season" with the child's birth. Nature motifs relating to the particular month or season of the year are preferred over numbers as they make it possible to reflect the time of birth and at the same time create pleasant images and associations alluding to the desired character traits and other aspirations for the child. The number seven can compete with these, as it is perceived as a lucky number, also creating various other associations than just reflecting the time of birth. Other numbers are usually chosen only if they repeatedly appear in the date (and time) of birth, or if the kanji representing a particular number is considered most suitable to accompany the phonological form (for example, by creating a favorable number of total strokes in the full name).

Finally, kanji representing numbers are often chosen by those who oppose the recent trend of the so-called kira kira nemu, contemporary names characterized by unusual phonological and graphic forms, often with a discordant character-sound relationship. Numerical kanji are appreciated for their simplicity and tradition. 


\section{Bibliography}

Atsuji, Tetsuji. 2005. "Namae" no kanjigaku. Tōkyō: Seishun Shuppansha,. Barešová, Ivona. 2015. Plant Motifs in Japanese Female Names in the Context of Current Name-giving Trends. Czech and Slovak Linguistic Review, no. 2, pp. 4-17.

Barešová, Ivona. 2016. Japanese Given Names: A Window Into Contemporary Japanese Society. Olomouc: Palacky University Press,.

Barešová, Ivona. 2017. Chrysanthemum, Pine and Crane - Female Names of Meiji Period Japan.Studia Orientalia Slovaca 16, no. 2, pp. 39-67.

Barešová, Ivona. 2018. Čísla v japonských rodných jménech v minulosti a dnes. Nový Orient 73, no. 1, pp. 37-43.

Honda, Akiko. 2005. Akachan no nazuke. Nihongogaku 24, pp.: 54-62.

Jugaku, Akiko. 1979. Nihonjin no namae. Tōkyō: Taishūkan Shoten..

Kobayashi, Yasumasa. 2009. Nazuke no sesōshi. "Koseiteki na namae" o firudowāku. Tōkyō: Fūkyōsha.

Makino, Kunio. 2012. Kodomo no namae ga abunai. Tōkyō: Besuto serāzu,.

Meiji Yasuda. 2017. http://www.meijiyasuda.co.jp (access date: 20 November 2017).

Nakaya, Tereza. 2018. Snaha o jedinečnost - vliv společenských změn na volbu osobního jména v současném Japonsku. Dálný východ 2, no. 2, pp.18-30.

Satō, Minoru. 2007. Yominikui namae wa naze fueta ka. Tōkyō: Yoshikawa Kōbunkan. 